\title{
PENGARUH CARBON FIBER REINFORCED POL YMER (CFRP) TERHADAP BALOK BETON BERTULANG
}

\author{
Sri Rejeki Laku Utami \\ Jurusan Teknik Sipil, Fakultas Teknik dan Rekayasa, Universitas Selamat Sri \\ Email: udhitami@gmail.com
}

\begin{abstract}
The effect of Carbon Fiber Reinforced Polymer (CFRP) on reinforced concrete beams is expected to contribute to increased ductility. In this study five beam specimens. The first test object is a 3D16 Normal beam that is used as a normal beam. The second test object is a 3D16 CFRP beam which is used as a beam with CFRP treatment. The third test object is a 4D16 Normal beam that is used as a normal beam. The fourth test object is a 4D16 CFRP beam that is used as a beam with CFRP treatment. The fifth test object is the 5D16 CFRP beam used as a beam with CFRP treatment. The dimensions of the beams are $150 \times 250 \mathrm{~mm}$, with an effective length of $2000 \mathrm{~mm}$. Pembebanan diberikan One Point Loads, untuk melakukan uji lentur maka pembebanan pada balok direncanakan dengan menempatkan satu buah gaya $P$ secara simetris pada jarak $1 / 2 \mathrm{~L}$ yaitu sebesar $1000 \mathrm{~mm}$. Dan diberikan perlakuan CFRP pada balok 3D16 CFRP sepanjang $600 \mathrm{~mm}(2,4 \mathrm{~h})$ ditengah bentang yang panjangnya $2.000 \mathrm{~mm}$ dengan perlakuan CFRP Completely Wrapped Member. From the results of testing the maximum flexural capacity in a row for the 3D16 Normal beam is $104.04 \mathrm{kN}$ while the 3D16 CFRP beam has a maximum increase in bending capacity of $119.52 \mathrm{kN}$ while the 4D16 Normal beam has a maximum bending capacity of $161.28 \mathrm{kN}$ while the 4D16 beam CFRP has a maximum increase in bending capacity of $162.64 \mathrm{kN}$, while the 5D16 CFRP beam has a maximum increase in flexural capacity of $173.16 \mathrm{kN}$.
\end{abstract}

Keyword: CFRP (Carbon Fiber Reinforced Polymer), Flexural Strength

\begin{abstract}
ABSTRAK
Pengaruh Carbon Fiber Reinforced Polymer (CFRP) pada balok beton bertulang diharapkan memberikan konstribusi terhadap peningkatan daktilitas. Pada kajian ini lima buah benda uji balok. Benda uji pertama adalah balok 3D16 Normal yang digunakan sebagai balok normal. Benda uji ke dua adalah balok 3D16 CFRP yang digunakan sebagai balok dengan perlakuan CFRP. Benda uji ke tiga adalah balok 4D16 Normal yang digunakan sebagai balok normal. Benda uji ke empat dalah balok 4D16 CFRP yang digunakan sebagai balok dengan perlakuan CFRP. Benda uji ke lima dalah balok 5D16 CFRP yang digunakan sebagai balok dengan perlakuan CFRP. Dimensi balok - balok tersebut adalah 150 × $250 \mathrm{~mm}$, dengan panjang efektif $2000 \mathrm{~mm}$. Pembebanan diberikan One Point Loads, untuk melakukan uji lentur maka pembebanan pada balok direncanakan dengan menempatkan satu buah gaya $P$ secara simetris pada jarak $1 / 2 \mathrm{~L}$ yaitu sebesar $1000 \mathrm{~mm}$. Dan diberikan perlakuan CFRP pada balok 3D16CFRP sepanjang $600 \mathrm{~mm}(2,4 \mathrm{~h})$ ditengah bentang yang panjangnya $2.000 \mathrm{~mm}$ dengan perlakuan CFRPCompletely Wrapped Member. Dari hasil pengujian kapasitas lentur maksimum secara berturut- turut untuk balok 3D16 Normal sebesar 104,04 kN sedangkan pada balok 3D16 CFRP mengalami peningkatan kapasitas lentur maksimum sebesar 119,52 kN sedangkan balok 4D16 Normal memiliki kapasitas lentur maksimum sebesar 161,28 kN sedangkan balok 4D16 CFRP mengalami peningkatan kapasitas lentur maksimum sebesar 162,64 kN, sedangkan balok 5D16 CFRP mengalami peningkatan kapasitas lentur maksimum sebesar $173,16 \mathrm{kN}$.
\end{abstract}

Kata kunci: CFRP (Carbon Fiber Reinforced Polymer), Kuat Lentur 


\section{PENDAHULUAN}

Beton bertulang merupakan kombinasi yang baik antara beton dengan baja tulangannya. Beton mempunyai perilaku keruntuhan getas, yaitu keruntuhan yang terjadi secara tiba tiba jika beban yang bekerja sudah melampui kekuatan bahan, sementara baja mempunyai perilaku keruntuhan daktail, yaitu adanya peristiwa kelelehan sebelum bahan runtuh akibat pembebanan yang diberikan. Pemberian perkuatan pada elemen balok beton bertulang, berupa perkuatan CFRP merupakan salah satu usaha untuk meningkatkan kekuatan, kekauan dan daktilitas beton bertulang. Perkuatan CFRP pada balok beton bertulang diharapkan memberikan konstribusi terhadap peningkatan daktilitas.

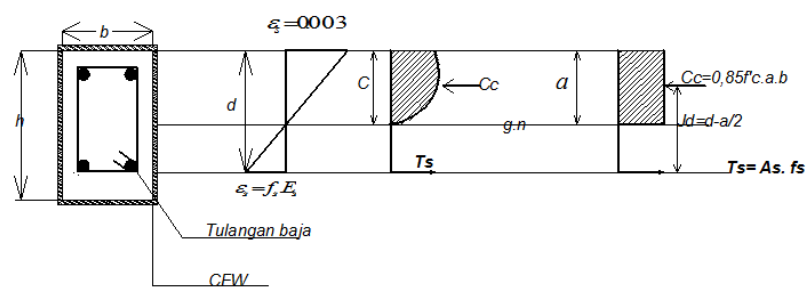

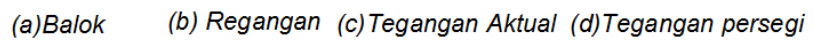

Gambar 1. Pengaruh penempatan tulangan baja terhadap jarak jd pada diagram tegangan.

Besarnya kapasitas momen yang dihasilkan oleh beton bertulang salah satunya ditentukan oleh penempatan tulangan baja di dalam beton (jarak Jd). semakin besar jarak Jd maka kapasitas momen yang dikehendaki dapat bekerja optimal maka tulangan harus diletakkan diserat tarik balok yang paling jauh, dengan kata lain $J d$ diupayakan maksimum, dimana $J_{d_{2}}>J_{d}$ sehingga $M_{2}>M_{1}$ seperti terlihat pada Gambar 1. Pengaruh penempatan tulangan baja terhadap jarak jd pada diagram tegangan.

Daktilitas adalah kemampuan suatu struktur bangunan untuk mengalami simpangan pasca elastis yang secara besar berulang kali dan siklik akibat beban gempa di atas beban gempa yang menyebabkan terjadinya pelelehan pertama, sambil mempertahankan kekuatan dan kekauan yang cukup. Sehingga struktur bangunan gedung tersebut tetap berdiri walaupun sudah berada dalam kondisi plastis. Penambahan tulangan tekan $2 \varnothing 6 \mathrm{~mm}$ untuk mempengaruhi tulangan tekan sangat kecil dan untuk memperkecil pengaruh tulangan tekan dengan adanya penambahan CFRP agar beton terkekang (external confinement).

Pembalutan CFRP pada balok beton bertulang diharapkan memberikan konstribusi terhadap peningkatan daktilitas. Dengan menggunakan model konstitutif (kurva hubungan teganganregangan) beton terkekang, dibuat program analisis untuk mengetahui sejauh mana pengaruh Perlakuan $C F R P$ terhadap daktilitas balok beton bertulang dan kapasitas penampang balok beton bertulang. Berdasarkan latar belakang permasalahan di atas maka perlu dilakukan kajian tentang "Pengaruh CFRP Terhadap Balok Beton Bertulang". Manfaat yang ingin diperoleh dari kajian ini antara lain bertambahnya wawasan dan pengetahuan dan memahami permasalahan teknologi beton. Khususnya mengenai pengaruh balok beton bertulang oleh CFRP terhadap balok beton bertulang. Sebagai masukan standar/Code SNI dan perngaruh CFRP pada balok bertulang. Agar eksperimen dapat terarah sesuai tujuan yang diharapkan, dipakai 
anggapan dasar dan batasan bahan sebagai berikut:

1. Tulangan yang digunakan adalah sebagai berikut

a. Baja ulir diameter $16 \mathrm{~mm}$ untuk tulangan tarik

\section{Perilaku Mekanik Beton}

Komposisi campuran beton akan mempengaruhi kekuatan tekan beton. Jumlah pasta semen harus cukup untuk membalut seluruh permukaan butiran agregat yang ada. Sifat dan jenis agregat yang digunakan berpengaruh terhadap kuat tekan beton yang tinggi pula. Perilaku kekuatan tekan beton normal dapat b. Baja polos diameter $6 \mathrm{~mm}$ untuk tulangan tekan.

c. Baja polos diameter $8 \mathrm{~mm}$ dengan jarak $100 \mathrm{~mm}$ untuk tulangan geser.

2. Peninjauan dilakukan hanya terhadap perilaku lentur dan geser.

diperlihatkan dengan menggunakan kurva parabola tegangan regangan Hognestad terlihat pada Gambar 2. Kurva Parabola Regangan-Tegangan Beton Hognestad untuk beton mutu normal (Park \& Paulay, 1975) dengan persamaan kuat tekan beton sebagai berikut (Park \& Paulay, 1975).

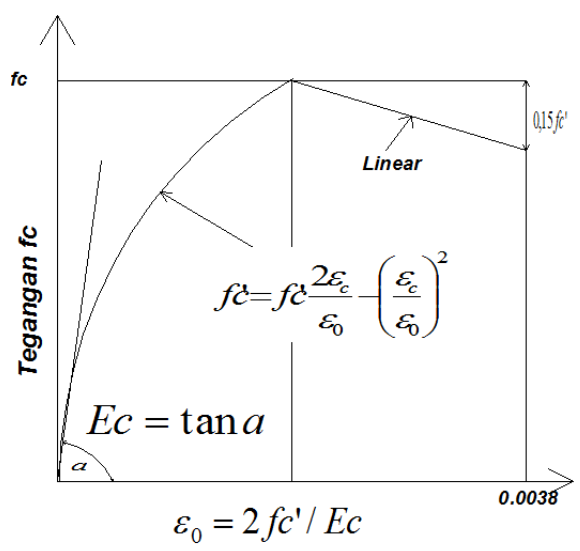

Gambar 2. Kurva Parabola Regangan-Tegangan Beton Hognestad untuk beton mutu normal (Park \& Paulay, 1975).

$$
f c^{\prime}=\frac{n \cdot f_{c o}\left(\frac{\varepsilon_{c}}{\varepsilon_{o}}\right)}{n .-1+\left(\frac{\varepsilon_{c}}{\varepsilon_{o}}\right)^{n k}}
$$

Untuk daerah $\mathrm{AB}\left(0 \leq \varepsilon_{\mathrm{c}} \leq \varepsilon_{\mathrm{co}}\right)$ harga $\mathrm{k}=1$ jika $\frac{\varepsilon_{c}}{\varepsilon_{o}} \leq 1$

Untuk daerah $\mathrm{BC}\left(\varepsilon_{\mathrm{c}}>\varepsilon_{\mathrm{co}}\right)$ harga $\mathrm{k}=0,67$ $+\frac{f_{c^{\prime}}}{62}$ Mpa jika $\frac{\varepsilon_{c}}{\varepsilon_{o}}>1$

$\mathrm{E}_{\mathrm{c}}=3320 \sqrt{f^{\prime}}+6900 \mathrm{MPa}$

$$
\begin{aligned}
& \varepsilon_{c o}=\frac{f c^{\prime} \cdot n}{E_{c} \cdot n-1} \\
& n=0,8+\frac{f c^{\prime}}{17} M P a
\end{aligned}
$$

Beton yang dibebani dengan gaya multiaxial akan mengalami peningkatan tegangan axial dan daktilitas, jika dibandingkan dengan beton yang dibebani gaya uniaxial. Hal ini disebabkan oleh adanya gaya lateral tekan yang diberikan oleh kekangan (confinment) pada beton tersebut. Gaya lateral tekan ini akan menahan deformasi lateral beton apabila diberikan gaya axial. Selain meningkatkan 
kapasitas axial, tegangan lateral yang bekerja pada beton akan meningkatkan daktilitas kolom tersebut. Deformasi dari beton yang mengalami retak akan meningkatkan daktilitas kolom tersebut. Deformasi dari beton yang mengalami retak akan terhambat karena adanya tekanan lateral kekangan, sehingga kurva tegangan- regangan beton akan menunjukan penurunan yang lebih landai setelah puncak.

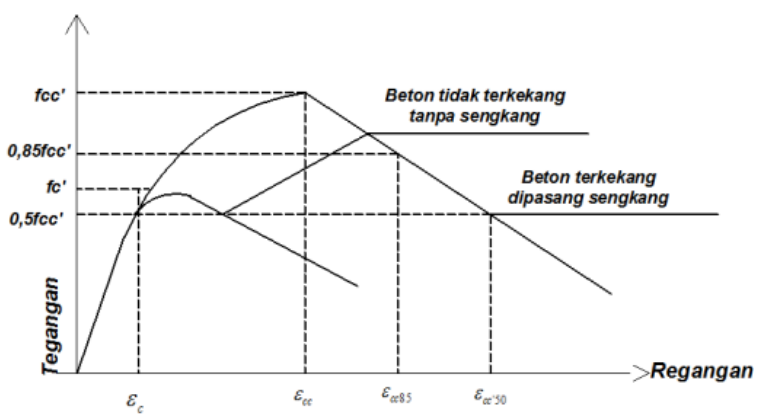

Gambar 3. Grafik tegangan-regangan beton terkekang dan beton tidak terkekang.

Pada Gambar 3. Grafik teganganregangan beton terkekang dan beton tidak terkekang, terlihat bahwa pada tegangan awal modulus elasitas beton terkekang dengan beton tidak terkekang hampir sama berarti pada tegangan awal tersebut, tulangan lateral belum aktif memberikan tahanan lateral. Deformasi lateral yang disebabkan oleh beban aksial yang bekerja pada beton, medapatkan tahanan dari ikatan antara partikel beton "Poisson Ratio" yang merupakan perbandingan antara deformasi lateral dengan aksial antara beton terkekang dengan beton tidak terkekangpun sama.

Model konsitutif beton (kurva hubungan tegangan-regangan beton) yang menggambarkan perilaku beton, biasanya diperoleh dengan menerapkan beban tekan aksial pada benda uji beton seperti kubus beton, dapat juga digunakan dengan menerapkan koefisien konversi yang sesuai. Salah satu model konstitutif beton (kurva hubungan tegangan-regangan beton) untuk beton normal yang sering digunakan dalam analisis beton bertulang adalah kurva hubungan teganganregangan Hognestad. Pendekatan umum digunakan pada model kurva hubungan tegangan-regangan beton sebelum mencapai tegangan maksimumnya adalah berbentuk parabola berderajat dua. Walaupun demikian bagian awal kurva dianggap linear sampai tegangan beton 0,5 $f c$ '. Kemiringan garis lurus bagian awal kurva (pada daerah elastis) didefinisikan sebagai modulus elastisitas $E_{c}$. Untuk kurva hubungan tegangan-regangan Hognestad.

\section{Kapasitas Lentur}

Kapasitas lentur adalah lentur yang terjadi pada balok dengan mengkondisikan gaya lintangnya sama dengan nol, yaitu dengan meletakan balok beton pada tumpuan sederhana yang dibebani secara simetris sejauh $1 / 2 L$ dari tumpuan (Prihadi, 2016).

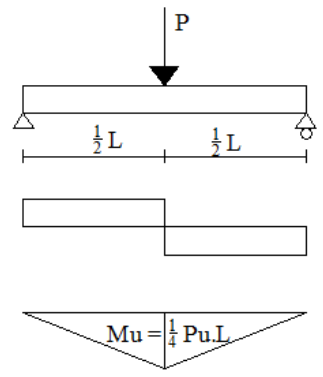

Gambar 4. Pola Pembebanan 
$\mathrm{Cc}=\mathrm{Ts}=>\mathrm{Cc}=0,85 . f c^{\prime} \cdot \mathrm{ab} \cdot \mathrm{b}$

$\mathrm{Ts}=$ As. $\mathrm{fs}=$ As. $f y . \mathrm{cb}=0,003 \cdot \mathrm{d} /(0,003+$ $\varepsilon s$ bila $\varepsilon s=f y /$ Es dengan $\mathrm{Es}=200.000$ Mpa, maka $\mathrm{cb}=600 \mathrm{~d} /(600+f y)$

$a b=\beta_{1}$. cb ; bervariasi misalnya $\beta_{1}=0,85$ untuk $f c^{\prime} \leq 30 \mathrm{MPa}$ $a b=\beta 1.600 . d /(600+f y) ;$ agar penulangan liat

maka digunakan $=>a=0,75 . a b=\beta 1.450$. $\mathrm{d} /(600+f y)$, a merupakan fungsi dari $d(\beta 1$ dan fy diketahui)

\section{Daktilitas}

Daktilitas merupakan kemampuan struktur atau sub-struktur untuk menahan respon inelastik yang dominan dalam memikul beban agar tidak runtuh.

Macam-macam daktilitas menurut Paulay \& Priestly (1992) antara lain adalah

a. Daktilitas kelengkungan (Curvature Ductility, $\mu_{\phi}$ ) merupakan perbandingan sudut kelengkungan (Angle Of Curvature) maksimum dengan sudut kelengkungan leleh elemen struktur akibat momen lentur. $\mu \phi=\frac{\phi u, \max }{\phi y}$

b. Daktilitas perpindahan (Diplacement Ductility), merupakan
$\mathrm{Cc}=0,85 . \mathrm{fc}^{\prime} \cdot \mathrm{b} \cdot \mathrm{a}$

$M n=T s(d-1 / 2 . a)=C c(d-1 / 2 \cdot a)=0,85 . f c '$. b.a $(d-1 / 2 . a)$

Bila $\mathrm{Mn}$ disamakan dengan $\mathrm{Mu} / \phi$ dan memasukkan a kedalam persamaan terakhir maka akan di dapatkan fungsi kuadrat dalam $\mathrm{d}$ bila $\mathrm{b}$ ditetapkan untuk mendapatkan nilai ukuran tampang balok.

perbandingan perpindahan (deformasi) maksimum struktur (arah lateral) dalam kondisi PostElastic terhadap perpindahan deformasi struktur saat leleh.

$$
\mu=\frac{\Delta u, \max }{\Delta y}
$$

\section{CFRP}

CFRP merupakan bahan perkuatan lentur dan dipasang pada permukaan bawah balok. Material CFRP biasanya digunakan sebagai perkuatan geser, baik pada kolom maupun balok. Namun, demikian berdasarkan sifat mekanis yang dimilkinya CFRP mempunyai kuat tarik yang sangat tinggi.

\begin{tabular}{cc}
\multicolumn{2}{c}{ Tabel 1. Karakteristik material Sika Wrap Hex 231 C } \\
\hline Properties & Sika Wrap \\
\hline Tensile Strength & $4.800 \mathrm{~N} / \mathrm{mm}^{2}$ \\
\hline E-Modulus & $234.000 \mathrm{~N} / \mathrm{mm}^{2}$ \\
\hline Elogation at break & $>1.8 \%$ \\
\hline Fabric Design & $0,131 \mathrm{~mm}$ ( based \\
Thickness & on fibre content) \\
\hline Width & $500 \mathrm{~mm}$ \\
\hline Fabric Length / roll & $100 \mathrm{~m}$ \\
\hline Sumber: PT. Sika Nusa Pratama Cabang Semarang. \\
\hline
\end{tabular}

Gambar 5. Cara Pemakaian CFRP jenis Sika Hex 231 C. 


\section{Bahan Epoxy (Perekat)}

Penggunaan CFRP sebagai tulangan eksternal pada struktur beton memerlukan bahan pengikat agar diperoleh aksi komposit antara beton dan CFRP. Data teknis tentang epoxy adhesives merupakan data sekunder dari PT. Sika Nusa Pratama selaku produsen. Perekat yang dipakai adalah epoxy adhesives jenis
Sikadur ®-330, yang terdiri dari dua komponen, yaitu komponen A yang berwarna putih dan komponen $B$ yang berwarna abu-abu tua. Perbandingan antara campuran komponen A: komponen $B$ adalah 4:1 dan warna setelah tercampur adalah abu-abu terang. Konsumsi perekat (bahan $A+$ bahan $B$ ) sebesar $1.30 \pm 0.1$ $\mathrm{kg} / \mathrm{l}($ part $A+B)\left(a t+23^{\circ} C\right)$ (evacuated) yang di oleskan pada permukaan beton.

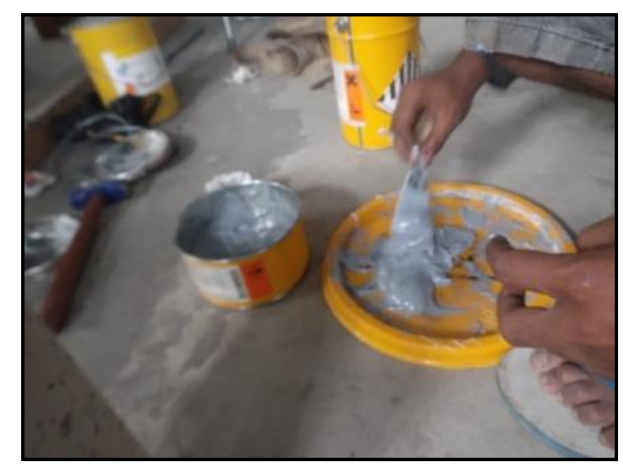

Gambar 6. Epoxy adhesives jenis Sikadur®-330.

Prihanantio dan Pangestuti (2006) mengungkapan bahwa untuk melakukan penelitian dengan CFRP yang dilakukan dengan 4 buah benda uji yaitu 1 buah balok uji sebagai balok kontrol tanpa perkuatan (BK) dan 3 buah balok yang lain diberi $C F R P$ dengan variasi yang berbeda yaitu BCFRP- $1 / 2 \mathrm{~b}$, BCFRP- $b$, dan BCFRP-U. Balok beton bertulang bentang $2000 \mathrm{~mm}$ dengan lebar $150 \mathrm{~mm}$ dan tinggi $250 \mathrm{~mm}$. Benda uji terbuat dari beton dengan kuat tekan $f c^{\prime}=34,4 \mathrm{Mpa}$. Dua buah tulangan tarik diameter $10 \mathrm{~mm}(2 \varnothing 10 \mathrm{~mm})$ dengan tegangan leleh fy $=340 \mathrm{Mpa}$ ditempatkan dalam kedalaman 203,5 mm. Perkuatan lentur dengan CFRP selebar $1 / 2 \mathrm{~b}$ (BCFRP$1 / 2$ b) pada bagian sisi tariknya menyebabkan kenaikan kapasitas momen sebesar $72,22 \%$, daktilitas naik sebesar $119,3 \%$ terhadap balok kontrol dan efektifitas CFRP sebesar $36 \%$. Perkuatan lentur dengan CFRP selebar b (BCFRP- $b)$ pada bagian sisi tariknya menyebabkan kenaikan momen sebesar 91,71\%, daktilitas balok naik sebesar 233,33\% terhadap BK. Efektifitas CFRP sebesar $48,67 \%$. Perkuatan CFRP model U (BCFRP-U) dapat meningkatkan kapasitas momen sebesar $8,33 \%$ daktilitas balok naik sebesar 7,72 \% terhadap BK. Efektifitas CFRP sebesar 1,33 \%. Maka Perkuatan lentur menggunakan CFRP dapat meningkatkan kapasitas lentur balok. Namun BCFRP-b yang paling signifikan jika dibandingkan terhadap BK. Pada $B C F R P-U$ pemasangan CFRP model tersebut sangat tidak efektif, karena seratnya searah dengan pola retak yang terjadi pada balok. Pada eksperimen ini CFRP mengalami putus pada daerah geser baik pada BCFRP- $1 / 2$ b maupun $B C F R P-\mathrm{b}$. Hal ini dikarenakan ketika beton runtuh CFRP mendapatkan hentakan secara tiba tiba sehingga mengakibatkan putus. Dalam hal ini dikatakan bahwa Epoxy cukup kuat menahan beban sehingga tidak terjadi debonding antara beton dengan CFRP (Prihanantio dan Pangestuti, 2006). 


\section{METODE}

Pada tahap ini dilakukan perencanaan balok uji, perencanaan Set Up pembebanan, dan perhitungan beban rencana yang akan bekerja pada struktur balok beton bertulang. Balok uji terbuat dari beton dengan kuat tekan beton rata-rata hasil mix design $f^{\prime} c=30 \mathrm{Mpa}$. Balok uji mempunyai penampang persegi dengan ukuran lebar $150 \mathrm{~mm}$, tinggi $250 \mathrm{~mm}$ dan bentang $2000 \mathrm{~mm}$. Dengan tulangan tarik dengan diameter $16 \mathrm{~mm}$ ( 3Ø16), ( 4Ø16) dan (5Ø16 CFRP) diletakan dengan kedalaman $203,5 \mathrm{~mm}$. Tulangan tarik yang digunakan adalah tulangan ulir dengan tegangan leleh ( $f y$ ) sebesar 409,3438 MPa. Penulangan direncanakan dengan rasio luas tulangan $(\rho)$ lebih kecil dari rasio penulangan maksimum $(\rho \leq 0,75 \rho b)$ yang memenuhi persyaratan sistem tulangan undereinforced. Sedangkan material komposit CFRP ditambahkan pada balok uji eksternal, CFRP dipasang pada permukaan bawah bahan. Agar terjadi keruntuhan lentur maka di daerah geser balok diperkuat dengan tulangan geser yaitu dengan menempatkan begel- begel yang berinterval $100 \mathrm{~mm}$. Begel tersebut menggunakan tulangan polos dengan diameter $8 \mathrm{~mm}$.

Guna mendapatkan beban rencana pada pengujian lentur balok maka dilakukan analisa perhitungan kapasitas penampang balok bertulang tunggal. Pada analisa tersebut balok mempunyai dua bahan yang berbeda yang akan menahan gaya yang berbeda, yaitu beton menahan gaya tekan sedangkan tulangan baja menahan gaya tarik. Momen kapasitas penampang balok dihitung dari kopel momen gaya-gaya dalam tersebut. Setelah besarnya momen kapasitas penampang diketahui, maka besarnya beban luar dapat dihitung dan dipakai sebagai beban rencana balok.

Pemasangan CFRP pada balok 3D16 dengan perlakuan $C F R P$, balok 4D16 CFRP serta balok 5D16 sepanjang 600 $\mathrm{mm}(2,4 \mathrm{~h})$ di tengah bentang yang panjang bentangnya $2.000 \mathrm{~mm}$ (2 meter) dengan pemasangan CFRP Completely Wrapped Member.Benda uji berupa balok bertulang yaitu 8 silinder beton normal, 1 silinder beton yang diperkuat dengan CFRP , 2 Balok Normal, 2 Balok yang diperkuat dengan CFRP.

Tabel 2.Variabel Pengujian Benda Uji

\begin{tabular}{ccc}
\hline No & Benda Uji & Perlakuan \\
\hline 1. & $\begin{array}{c}\text { 1 Balok Normal dengan } \\
\text { Tulangan tarik 3D16 }\end{array}$ & $\begin{array}{c}\text { Tanpa } \\
\text { CFRP }\end{array}$ \\
\hline 2. & 1 Balok dengan & Diperkuat \\
& Tulangan tarik 3D16 & $\begin{array}{c}\text { dengan } \\
\text { CFRP }\end{array}$ \\
\hline 3. & 1 Balok Normal dengan & Tanpa \\
& Tulangan tarik 4D16 & CFRP \\
\hline 4. & 1 Balok dengan & Diperkuat \\
& Tulangan tarik 4D16 & dengan \\
& & CFRP \\
\hline 5 & 1 Balok dengan & Diperkuat \\
& Tulangan Tarik 5D16 & dengan \\
& & CFRP. \\
\hline
\end{tabular}

a. Balok Beton Normal 3D16 (Tanpa Perkuatan CFRP).

Balok Beton Normal 3D16 (Tanpa Perkuatan CFRP) ini menggunakan tulangan lentur 3D16 mm, tulangan sengkang $\varnothing 8 \mathrm{~mm}-100 \mathrm{~mm}$, dan Tulangan Tekan $2 \varnothing 6 \mathrm{~mm}$. Adapun untuk lebih jelasnya dapat dilihat pada Gambar 7. Balok Beton 3D16 Normal.

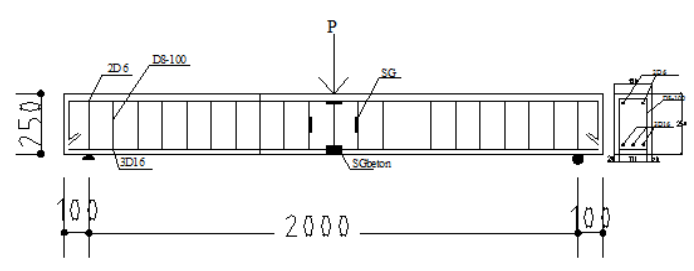

Gambar 7. Balok Beton 3D16 Normal.

b. Balok Beton 3D16 dengan Perlakuan CFRP.

Balok Beton 3D16 dengan perlakuan CFRP ini menggunakan tulangan lentur $3 \mathrm{D} 16 \mathrm{~mm}$, tulangan sengkang Ø8mm $100 \mathrm{~mm}$, dan Tulangan Tekan $2 \varnothing 6$ $\mathrm{mm}$. CFRP dipotong- potong sesuai dengan ukuran desain yang telah direncanakan. Pada kajian ini ukuran CFRP dari PT. Sika Nusa Pratama 
memiliki panjang $550 \mathrm{~mm}$ dan lebar $100 \mathrm{~mm}$. Pemasangan CFRP sepanjang $600 \mathrm{~mm}(2,4 \mathrm{~h})$ dari bentang akan tetapi dikarenakan panjang $C F R P$ $550 \mathrm{~mm}$ akan mengalami pengurangan sebesar $50 \mathrm{~mm}$ dilakukan penambahan sebesar $100 \mathrm{~mm}$ agar pemasangan $C F R P$ sesuai dengan perencanaan. Dan diberikan pemasangan CFRP pada balok 3D16 CFRP sepanjang 600 $\mathrm{mm}(2,4 \mathrm{~h})$ ditengah bentang yang panjang bentangnya $2.000 \mathrm{~mm}$ (2 meter) dengan pemasangan CFRP Completely Wrapped Member, untuk mengantispasi pembentukan sendi plastis seperti pada Gambar di bawah. Balok Beton 3D16 dengan perlakuan CFRP.

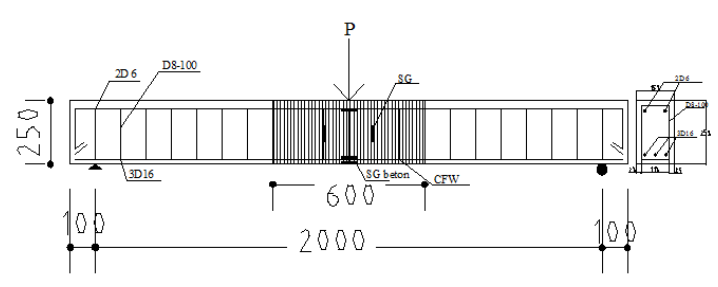

Gambar 8. Balok Beton 3D16 dengan perlakuan CFRP

c. Balok Beton 4D16 Normal (Tanpa Perlakuan CFRP).

Balok Beton 4D16 Normal (tanpa perlakuan CFRP) ini menggunakan tulangan lentur 4D16 mm, tulangan sengkang $\varnothing 8 \mathrm{~mm}-100 \mathrm{~mm}$, dan Tulangan Tekan $2 \varnothing 6 \mathrm{~mm}$. Adapun untuk lebih jelasnya dapat dilihat pada Gambar di bawah. Balok Beton 4D16 Normal (tanpa perlakuan CFRP).

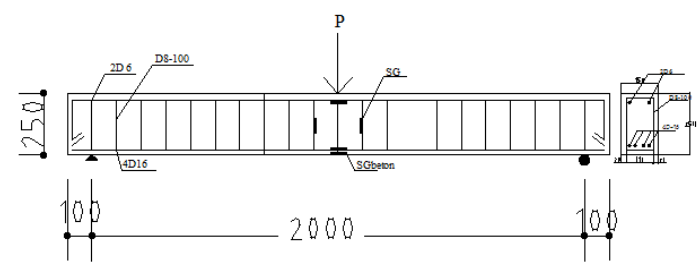

Gambar 9. Balok Beton 4D16 Normal.

d. Balok Beton 4D16 dengan Perlakuan CFRP.

Balok Beton 4D16 dengan perlakuan CFRP ini menggunakan tulangan lentur
4D16 mm, tulangan sengkang Ø8 mm$100 \mathrm{~mm}$, dan Tulangan Tekan $2 \varnothing 6$ $\mathrm{mm}$. CFRP dipotong- potong sesuai dengan ukuran desain yang telah direncanakan. Pada kajian ini ukuran CFRP dari PT. Sika Nusa Pratama memiliki panjang $550 \mathrm{~mm}$ dan lebar $100 \quad \mathrm{~mm}$. Pemasangan CFRPsepanjang $600 \mathrm{~mm}(2,4 \mathrm{~h})$ dari bentang akan tetapi dikarenakan panjang CFRP $550 \mathrm{~mm}$ akan mengalami pengurangan sebesar 50 $\mathrm{mm}$ dilakukan penambahan sebesar $100 \mathrm{~mm}$ agar pemasangan CFRP sesuai dengan perencanaan. Dan diberikan pemasangan CFRP pada 4D16 CFRP sepanjang $600 \mathrm{~mm}(2,4 \mathrm{~h})$ ditengah bentang yang panjang bentangnya $2.000 \mathrm{~mm}$ (2 meter) dengan pemasangan CFRPCompletely Wrapped Member, untuk mengantispasi pembentukan sendi plastis seperti pada Gambar 10. Balok Beton 4D16 dengan perlakuan CFRP.

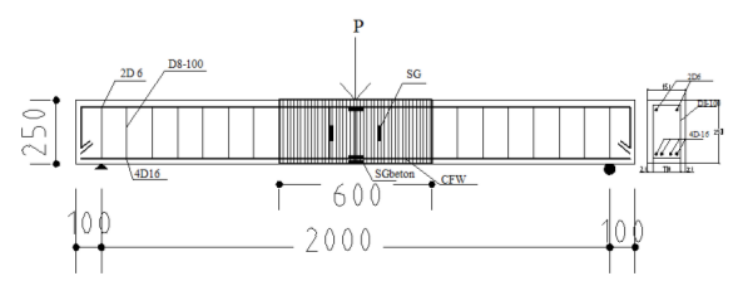

Gambar 10. Balok Beton 4D16 dengan Perlakuan CFRP

e. Balok Beton 5D16 dengan Perlakuan CFRP.

Balok Beton 5D16 dengan perlakuan $C F R P$ ini menggunakan tulangan lentur $5 \mathrm{D} 16 \mathrm{~mm}$, tulangan sengkang $\varnothing 8 \mathrm{~mm}-$ $100 \mathrm{~mm}$, dan Tulangan Tekan $2 \varnothing 6$ $\mathrm{mm}$. CFRP dipotong- potong sesuai dengan ukuran desain yang telah direncanakan. Pada kajian ini ukuran CFRP dari PT. Sika Nusa Pratama memiliki panjang $550 \mathrm{~mm}$ dan lebar $100 \mathrm{~mm}$. Pemasangan CFRP sepanjang $600 \mathrm{~mm}(2,4 \mathrm{~h})$ dari bentang akan tetapi dikarenakan panjang CFRP 550 $\mathrm{mm}$ akan mengalami pengurangan sebesar $50 \mathrm{~mm}$ dilakukan penambahan sebesar $100 \mathrm{~mm}$ agar pemasangan $C F R P$ sesuai dengan perencanaan. Dan diberikan pemasangan CFRP pada 4D16 CFRP sepanjang $600 \mathrm{~mm}$ 
(2,4 h) ditengah bentang yang panjang bentangnya $2.000 \mathrm{~mm}$ (2 meter) dengan pemasangan CFRP Completely Wrapped Member, untuk meng-antispasi pembentukan sendi plastis seperti pada Gambar 11. Balok Beton 5D16 dengan perlakuan CFRP.

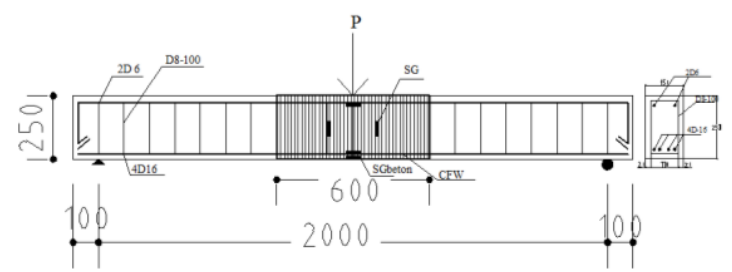

Gambar 11.Balok Beton 5D16 dengan Perlakuan CFRP

\section{Pemasangan Strain Gauge}

Guna mengetahui besarnya regangan pada beton, tulangan maupun CFRP dilakukan pemasangan Strain gauge pada bahan bahan tersebut di balok uji. Strain gauge yang dipakai dalam kajian ini terdiri dari dua macam yaitu type PL-60-11 dengan Panjang $60 \mathrm{~mm}$ yang dipakai untuk mengukur regangan beton dan type FLA 11 dengan panjang $6 \mathrm{~mm}$ yang dipakai untuk mengukur regangan $C F R P$, type ini juga bisa diapakai untuk mengukur regangan baja. Untuk mengetahui regangan beton, strain gauge dipasang pada permukaan beton bagian atas sisi tekan, sedang untuk CFRP dipasang pada permukaan bawah sisi tarik. Pada tempat tempat yang akan dipasang strain gauge permukaannya harus rata dan halus serta bersih dari kotoran. Semua kabel- kabel dari strain gauge dihubungkan ke Data Logger. Nilai regangan yang terjadi pada strain gauge dibaca lewat Data Logger, pemasangan strain gauge pada benda uji adalah sebagai berikut:

a. Balok Normal adalah Balok beton bertulang sebagai balok kontrol yang terdapat pada balok beton normal 3D16 Normal dan 4D16 Normal. Balok Normal ini akan dibandingkan dengan data - data dari balok uji yang dipasang dengan CFRP yang terdapat pada balok 3D16 CFRP dan balok 4D16 CFRP dan 5D16 CFRP, sehingga dapat diketahui perbedaannya. Pada balok normal strain gauge terpasang pada dua material yaitu beton dan tulangan baja. Strain gauge 1 dipasang pada permukaan serat tekan balok yang berfungsi untuk mendapatkan nilai regangan pada baja tulangan tekan ( $\left.\varepsilon s^{\prime}\right), 1$ strain gauge dipasang pada baja tulangan tarik $(\varepsilon s)$ yang berfungsi untuk mendapatkan nilai regangan pada baja tulangan tarik, 2 strain gauge dipasang pada tulangan baja sengkang yang berfungsi untuk mendapatkan nilai regangan pada tulangan sengkang, dan 1 strain gauge dipasang pada beton tarik yang berfungsi untuk mendapatkan nilai regangan pada beton tarik. Nilai regangan tarik tulangan baja dipakai untuk membuat grafik beban- regangan $(P-\varepsilon)$ dari kedua bahan tersebut, sehingga dapat diketahui perilaku tulangan baja selama pembebanan berlangsung dan kondisi saat tulangan mulai leleh.

b. Balok CFRP adalah Balok beton bertulang sebagai balok perlakuan dengan pembalutan CFRP yang terdapat pada balok beton CFRP 3D16 CFRP, 4D16 CFRP dan 5D16 CFRP. Balok CFRP ini akan dibandingkan dengan data - data dari balok uji yang tidak dipasang dengan CFRP yang terdapat pada balok 3D16 Normal dan balok 4D16 Normal, sehingga dapat diketahui perbedaannya. Pada Balok CFRP strain gauge terpasang pada dua material yaitu beton dan tulangan baja. Strain gauge 1 dipasang pada permukaan serat tekan balok yang berfungsi untuk mendapatkan nilai regangan pada baja tulangan tekan ( $\left.\varepsilon s^{\prime}\right), 1$ strain gauge dipasang pada baja tulangan tarik ( $\varepsilon s)$ yang berfungsi untuk mendapatkan nilai regangan pada baja tulangan tarik, 2 strain gauge dipasang pada tulangan baja sengkang yang berfungsi untuk mendapatkan nilai regangan pada tulangan sengkang, dan 1 strain gauge dipasang pada permukaan beton yang dipasang CFRP yang berfungsi untuk mendapatkan nilai regangan pada beton tarik yang dipasang dengan CFRP. Nilai regangan tarik tulangan baja dipakai untuk membuat grafik beban-regangan $(P-\varepsilon)$ dari kedua bahan tersebut, sehingga dapat 
diketahui perilaku tulangan baja selama pembebanan berlangsung dan kondisi saat tulangan mulai leleh.

\section{Pelaksanaan Pengecoran}

Pengecoran benda uji balok beton bertulang menggunakan ready mix berasal dari PT. Jati Kencana Beton.Pengecoran berlangsung di Laboratorium Bahan Universitas Diponegoro. Campuran beton segar dengan mutu $\mathrm{fc}^{\prime} 30 \mathrm{MPa}$ sebanyak $0,5 \mathrm{~m}^{3}$ dalam satu kali adukkan truk mixer dimasukkan ke dalam bekisting yang sudah diisi dengan rakitan tulangan utama dan tulangan sengkang. Sebelumnya, dilakukan kontrol uji nilai slump pada beton ready mix terlebih dahulu dan dilanjut dengan penuangan beton kedalam bekisting balok.

\section{Perawatan Benda Uji}

Perawatan dilakukan secara rutin dengan menutupi benda uji balok beton bertulang dengan karung basah dan menyiraminya setiap saat sampai berumur 28 hari. Sedangkan untuk benda uji silinder dibuka 24 jam kemudian di rendam ke dalam bak air.

\section{Pemasangan CFRP Pada Benda Uji Persiapan Balok}

Pemasangan CFRP dilakukan pada balok yang telah kering (kadar air 0\%). Selain itu, permukaan beton yang akan ditempel CFRP harus kasar agar rekatan lem dengan beton dapat lebih maksimal. Balok beton yang bebas air, digosok permukaannya dengan sikat baja untuk memperkasar permukaan balok. Setelah itu dilakukan penghalusan pada sisi siku balok. Sisi siku balok yang akan di tempel CFRP dibuat berbentuk seperempat lingkaran dengan menggunakan grenda. Hal ini dimaksudkan agar meminimalisir adanya sobekanCFRP pada siku balok yang tajam.

\section{Persiapan CFRP}

CFRP dipotong- potong sesuai dengan ukuran desain yang telah direncanakan. Pada kajian ini ukuran CFRP dari PT. Sika Nusa Pratama memiliki panjang $550 \mathrm{~mm}$ dan lebar $100 \mathrm{~mm}$. Pemasangan CFRPsepanjang $600 \mathrm{~mm} \quad(2,4 \mathrm{~h})$ dari bentang akan tetapi dikarenakan panjang
CFRP $550 \mathrm{~mm}$ akan mengalami pengurangan sebesar $50 \mathrm{~mm}$ dilakukan penambahan sebesar $100 \mathrm{~mm}$ agar pemasangan CFRP sesuai dengan perencanaan. Dan diberikan pemasangan CFRP pada balok 3D16 CFRP dan 4D16 CFRP sepanjang $600 \mathrm{~mm}(2,4 \mathrm{~h})$ ditengah bentang yang panjang bentangnya 2.000 $\mathrm{mm}$ (2 meter) untuk mengantispasi pembentukan sendi plastis.

\section{Pengeleman CFRP Pada Balok}

Perekat yang digunakan pada kajian ini menggunakan Sikadur®-330 produk dari PT. Sika Indonesia. Persiapan perekat dilakukan dengan mencampur campuran $A$ dan Campuran $B$ dengan perbandingan 4 : 1. Perekat disiapkan pada posisi CFRP dengan menggunakan kuas, dan CFRP ditempel pada posisi perekat dan di tekan tekan hingga perekat terlihat disamping sisi-sisi CFRP. Setelah itu, kuas kembali sisi CFRP dengan menggunakan perekat hingga $C F R P$ tertutup rapat oleh perekat. Adapun proses pengeringan CFRP ini, kekuatan ultimit perekat hingga hari ke-7 sehingga pengujian balok dilakukan setelah hari ke-7 pemasangan CFRP pada balok.

\section{Set Up Pengujian}

Benda uji balok beton bertulang ditempatkan pada Loading Frame dan tumpuan dikondisikan sendi-roll pada kedua ujungnya. Pengujian dilakukan dengan cara memberikan beban secara monotonik yang bersifat statik dengan interval kenaikan sebesar $200 \mathrm{~kg}$. Bentang bersih balok $2000 \mathrm{~mm}$ dan pembebanan dilakukan secara simetris di satu titik dengan jarak $1000 \mathrm{~mm}$ antar titik pembebanan dan diharapkan terjadi lentur murni. Untuk mengetahui pola retak yang terjadi pada model balok beton bertulang. Permukaannya dilapisi cat putih dan diberi garis saling tegak lurus sejarak $50 \mathrm{~mm}$. Untuk mengetahui defleksi yang terjadi maka pada balok uji dipasang tiga buah LVDT (Linear Variable Displacement Tranducers).

Dua buah ditemukan pada tumpuan dan satu buah di tengah bentang balok. 
Pengaruh Carbon Fiber ... (Sri/ hal 23-42)

Penempatan LVDT pada kedua tumpuan digunakan untuk mengontrol apabila gelagar yang menumpu balok tidak cukup kaku (melendut) selama pembebanan berlangsung sedangkan penempatan LVDT di tengah bentang digunakan untuk mengetahui besar lendutan maksimum kapasitas 50 ton dan load cell yang mempunyai kapasitas sebesar 60 ton. Pembebanan dilakukan secara bertahap dengan interval kenaikan sebesar $200 \mathrm{~kg}$. Pembebanan akan dihentikan jika benda uji sudah runtuh dan data logger yang membaca besarnya beban dari load cell tidak bertambah. Setting up alat dan pembebanan dari model balok beton bertulang dapat dilihat pada Gambar 11. Setting Up Pengujian balok lentur, sedangkan alur dalam kajian dapat dilihat pada Gambar 13. Data yang dicatat dalam meliputi:

a. Besarnya retak awal akibat pembebanan (first crack).

b. Beban pada saat terjadi first crack yang ditujukan di layar data logger.

c. Defleksi selama pembebanan berlangsung yang ditunjukan oleh LVDT. Defleksi di ukur di tiga titik yaitu satu titik ditengah bentang dan dua titik di bawah titik tumpuan. Defleksi yang dipakai untuk analisis adalah defleksi di tengah bentang karena dapat menunjukan defleksi yang maksimum.

d. Pola retak dan arah rambatan selama pembebanan

Pengamatan berlangsung. menggambarkan pola keruntuhan yang terjadi.

e. Besarnya beban pada saat runtuh yang di tunjukkan oleh data logger.

f. Besarnya regangan pada beton, baja dan pada CFRP yang ditunjukkan oleh data logger).

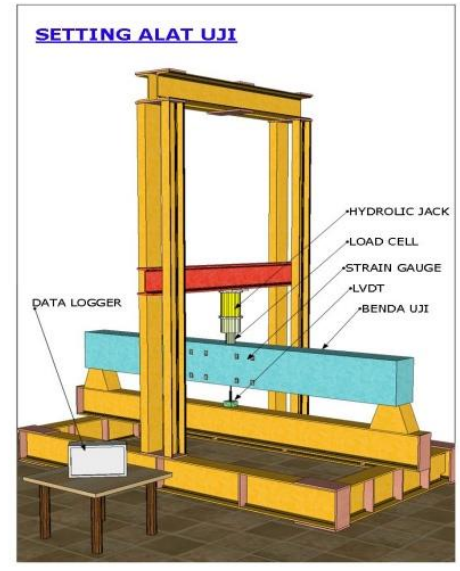

Gambar 12.Setting Up Pengujian balok lentur.

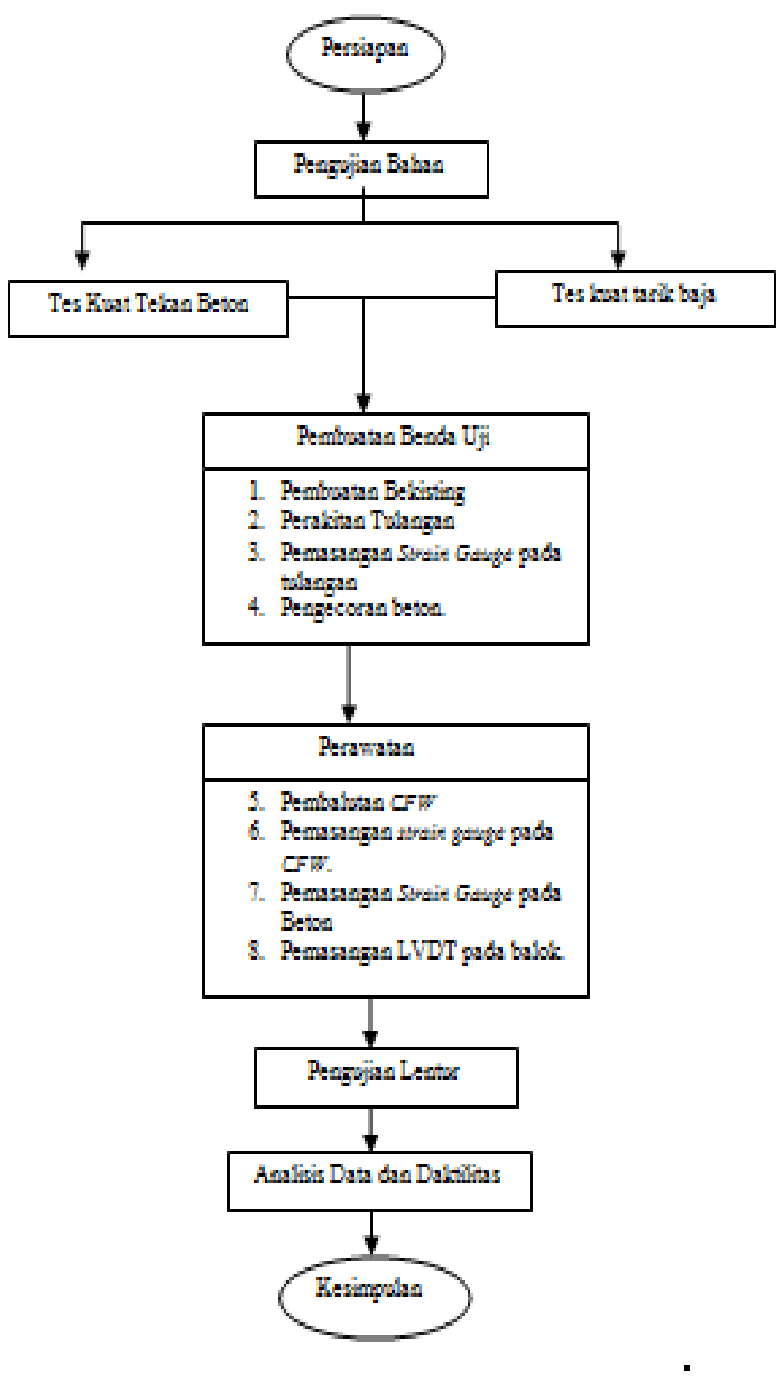

Gambar 13. Skema Tahapan Kajian 


\section{HASIL DAN PEMBAHASAN}

\section{Pengujian Kuat Tarik Baja}

Dari hasil tegangan leleh dan ultimit masing masing tulangan memilki hasil yang berbeda-beda, karena hasil produksi dari pabrik baja bahwa setiap tulangan memiliki kuat tarik belum tentu sama meskipun memiliki diameter yang sama. Tetapi perbedaan anatara kekuatan tulangan tidak terlalu besar dan masih bisa diterima. Tetapi perbedaan antara kekuatan tulangan tidak terlalu besar dan masih bisa diterima.
Dengan melihat hasil pengujian didapatkan tegangan leleh rata rata $\phi 6 \mathrm{~mm} f_{y}=339,9995$ $\mathrm{MPa}$, tegangan ultimit rata-rata $f_{u}=505,5523$ MPa. Untuk Tulangan $\phi 8 \mathrm{~mm} f_{y}=383,62915$ $\mathrm{MPa}$, tegangan ultimit rata-rata $f_{u}=534,8280$ $\mathrm{MPa}$. Untuk tulangan D16 $\mathrm{mm} f_{y}=409,34383$ $\mathrm{MPa}$, tegangan ultimit rata -rata $f_{u}=$ $593,9870 \mathrm{MPa}$. Modulus elastisitas $\left(\mathrm{E}_{\mathrm{s}}\right)$ baja tulangan $=200.000 \mathrm{MPa}$. Hasil pengujian dari kuat tarik baja tulangan ini adalah sebagai berikut:

Tabel 3. Hasil pengujian baja tulangan $\phi 6, \phi 8$ dan D16.

\begin{tabular}{|c|c|c|c|c|c|}
\hline No. & $\begin{array}{l}\text { Diameter } \\
(\mathrm{mm})\end{array}$ & $\begin{array}{c}F_{y} \\
(\mathrm{MPa})\end{array}$ & $\begin{array}{c}\text { Rata-rata } \\
F_{y} \\
(\mathrm{MPa}) \\
\end{array}$ & $\begin{array}{c}F_{u} \\
(\mathrm{MPa})\end{array}$ & $\begin{array}{c}\text { Rata-rata } F_{u} \\
(\mathrm{MPa})\end{array}$ \\
\hline 1. & $\phi 6-1$ & 360,0451 & \multirow{3}{*}{339,9995} & 504,0631 & \multirow{3}{*}{505,5523} \\
\hline 2. & $\phi 6-2$ & 317,2900 & & 498,5986 & \\
\hline 3. & $\phi 6-3$ & 342,6635 & & 513,9952 & \\
\hline 4. & $\phi 8-1$ & 372,0203 & \multirow{3}{*}{383,6292} & 534,7792 & \multirow{3}{*}{534,8280} \\
\hline 5. & $\phi 8-2$ & 388,8834 & & 542,0799 & \\
\hline 6. & $\phi 8-3$ & 389,9837 & & 527,6251 & \\
\hline 7. & D16-1 & 434,0435 & \multirow{3}{*}{409,3438} & 641,6295 & \multirow{3}{*}{593,9870} \\
\hline 8. & D16-2 & 373,3621 & & 506,2537 & \\
\hline 9. & D16-3 & 420,6259 & & 634,0778 & \\
\hline
\end{tabular}

\section{Pengujian Kuat Tekan Silinder}

Untuk memperoleh data kuat tekan beton yang digunakan beberapa sampel silinder beton untuk dilakukan pengujian kuat tekan beton.Pengujian kuat tekan silinder beton dilakukan pada umur 35 hari dan saat balok beton bertulang dilakukan pengujian geser. Pengujian kuat tekan silinder beton menggunakan Compression Test Machine. Dari hasil pengujian kuat tekan silinder beton dilakukan konversi umur 28 hari.Hasil pengujian kuat tekan silinder beton konversi 28 hari menunjukan nilai tekan beton ratarata $f c^{\prime}$ sebesar 43,28 MPa. Berdasarkan pengujian kuat tekan silinder beton ini dapat dilihat beton mengalami perbedaan terhadap kuat tekan beton yang direncanakan sebesar
$30 \mathrm{MPa}$. Sedangkan untuk silinder yang menggunakan CFRP memiliki nilai tekan $f c$ ' sebesar $48,43 \mathrm{MPa}$

\section{Pengujian Balok Beton Bertulang}

Hasil analisis data dapat disimpulkan bahwa dengan perkuatan CFRP ini, balok masih dapat menerima beban sebesar beban perkuatan CFRP. Balok beton 3D16 Normal memiliki kapasitas lentur sebesar 104,04 kN sedangkan 3D16 dengan perlakuan CFRP memilki kapasitas lentur 119,52 kN. Balok beton 4D16 Normal memilki kapasitas lentur sebesar 161,28 kN sedangkan 4D16 dengan perlakuan CFRP memiliki kapasitas lentur 162,64 kN sedangkan 5D16 untuk perlakuan CFRP memiliki kapasitas lentur 173,16 kN. 


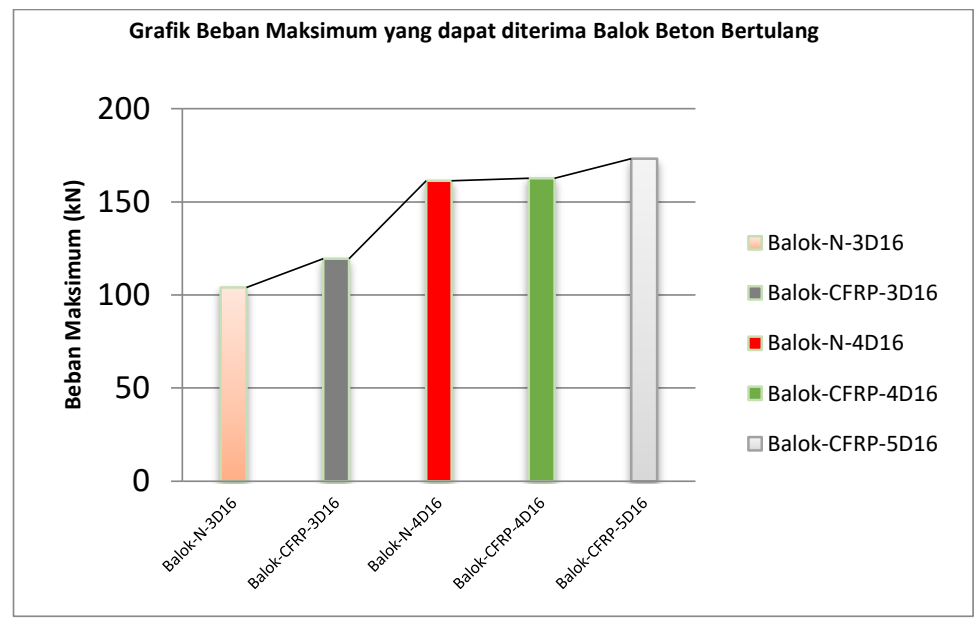

Gambar 14. Grafik beban maksimum yang dapat diterima balok beton bertulang.

\section{Balok beton bertulang tanpa menggunakan CFRP (3D16 Normal)}

Berdasarkan pengujian balok 3D16 Normal menghasilkan keruntuhan yang sesuai dengan keruntuhan rencana. Pengujian pada balok normal diperoleh nilai $P$ maksimum adalah sebesar 104,04 kN dan balok beton 3D16 Normal mengalami first crack sebesar 16,56 kN. Berdasarkan grafik hubungan beban-lendutan dapat dilihat pada Gambar 16. Hubungan antara beban dan lendutan pada balok 3D16 Normal (tanpa CFRP).
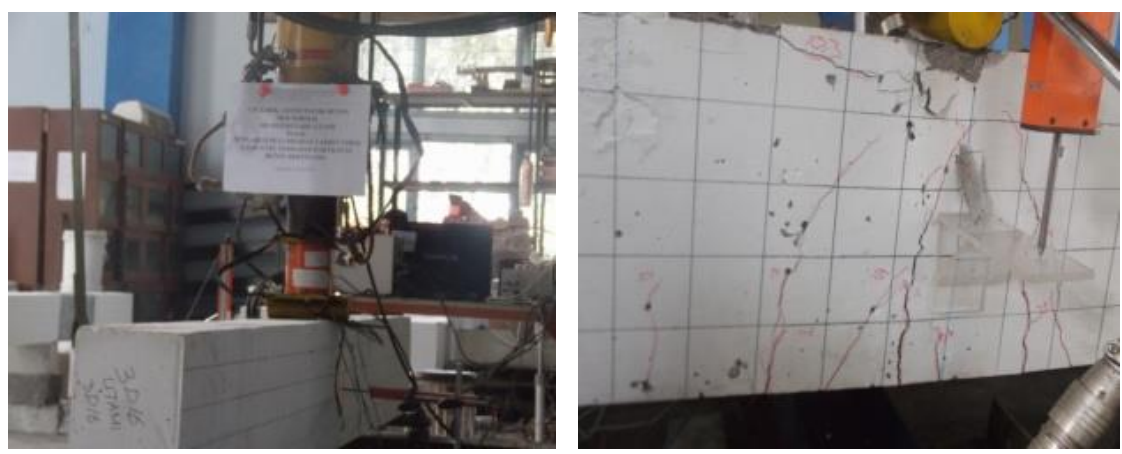

Gambar 15. Retak awal pada balok 3D16 Normal

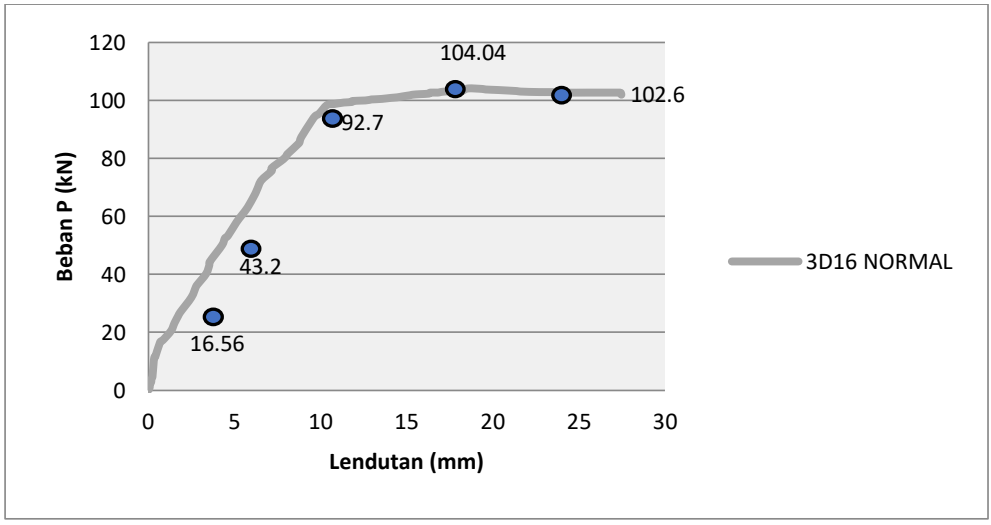

Gambar 16. Hubungan antara beban dan lendutan pada balok 3D16 Normal (tanpa CFRP). 
Pada $\mathrm{P}$ sebesar $16,56 \mathrm{kN}$ memiliki nilai $\varepsilon \mathrm{c}$ sebesar 0,0003 dan nilai $\varepsilon s$ sebesar 0,0002. Sedangkan pada $P$ sebesar $43,2 \mathrm{kN}$ memiliki nilai $\varepsilon c \quad 0,00156$ dan nilai $\varepsilon s$ sebesar 0,00092 . Sedangkan nilai $P$ sebesar $92,7 \mathrm{kN}$ memiliki nilai $\varepsilon c$ sebesar 0,00346 dan nilai $\varepsilon s$ sebesar 0,00212 . Sedangkan nilai $P$ sebesar 104,04 kN memiliki nilai $\varepsilon c 0,0052$ karena beton sudah runtuh (menurun) dan nilai $\varepsilon s$ sebesar 0,0039 . Dan pada saat beban $P$ sebesar 102,6 kN memiliki nilai $\varepsilon s$ 0,0037 tulangan besi sudah leleh dan beton sudah runtuh dengan nilai $\varepsilon c$ sebesar 0,0051 .

Pada $P$ sebesar 16,56 kN mencapai lendutan sebesar $0,68 \mathrm{~mm}$ dan saat $P$ mengalami penambahan beban sebesar $43,2 \mathrm{kN}$ maka lendutan yang di miliki sebesar $3,54 \mathrm{~mm}$. Sehingga untuk mencapai keruntuhan pada balok 3D16 Normal maka
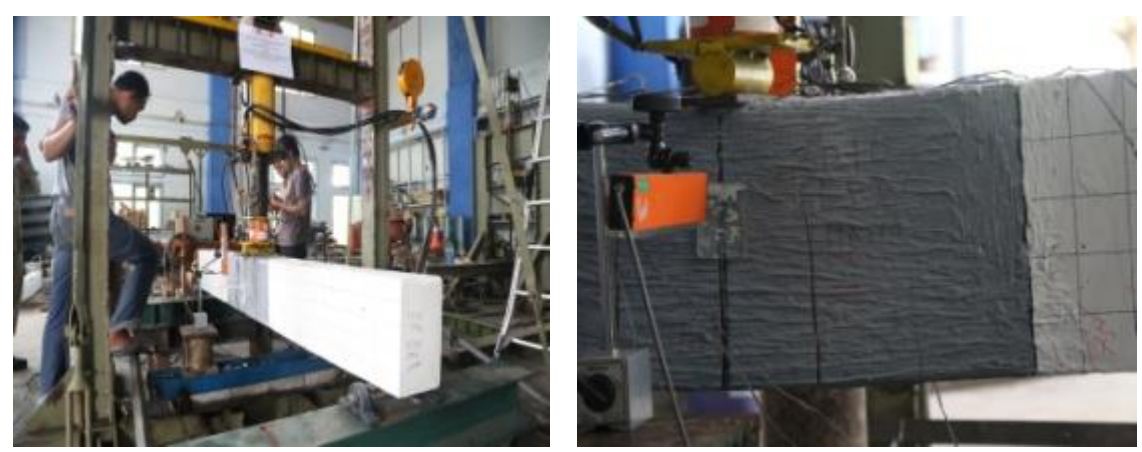

Gambar 17. Retak pertama yang terjadi pada balok 3D16 CFRP

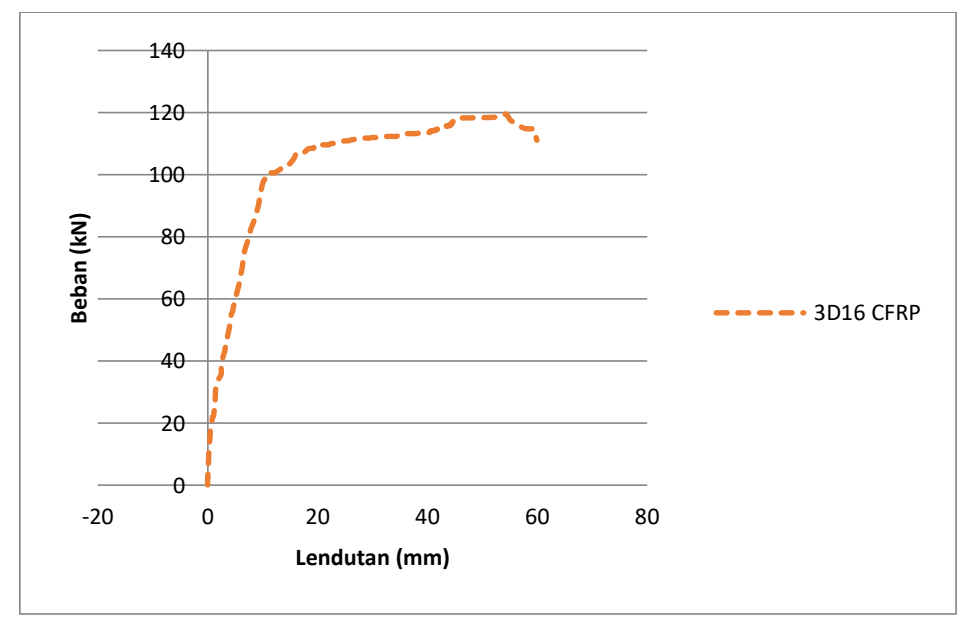

Gambar 18. Hubungan antara beban dan lendutan pada Balok 3D16 CFRP

Pada $\mathrm{P}$ sebesar $8,1 \mathrm{kN}$ memiliki nilai $\varepsilon \mathrm{c}$ sebesar 0,0001 dan nilai $\varepsilon s$ sebesar 0,0001. Sedangkan pada $P$ sebesar 49,5 kN memiliki nilai $\varepsilon c 0,0017$ dan nilai $\varepsilon s$ sebesar 0,0010 . Sedangkan nilai $\mathrm{P}$ sebesar 100,62 kN diperlukan penambahan $\mathrm{P}$ sebesar $92,7 \mathrm{kN}$ mencapai lendutan sebesar $9,46 \mathrm{~mm}$. Pada saat $P$ sebesar $104,04 \mathrm{kN}$ sudah mengalami keruntuhan pada balok 3D16 Normal dengan lendutan sebesar $18,56 \mathrm{~mm}$. Sehingga dapat dihitung daktilitas perpindahan dengan lendutan sebesar $\delta y=2,76 \mathrm{~mm}$. Sedangkan nilai $\delta u=38,08 \mathrm{~mm}$ sehingga diperoleh nilai daktilitas balok 3D16 Normal sebesar 13,7971 .

\section{Balok beton bertulang dengan menggunakan CFRP (3D16 CFRP).}

Retak Pertama yang terjadi pada balok beton bertulang perkuatan CFRP dapat dilihat pada Gambar 17. Retak pertama yang terjadi pada balok 3D16 CFRP terjadi saat beban menunjukan angka sebesar 8,1 kN. memiliki nilai $\varepsilon c$ sebesar 0,0215 dan untuk nilai $\varepsilon s \quad 0,0171$. Sedangkan pada $P$ sebesar 118,26 memiliki nilai $\varepsilon c$ sebesar 0,0365 karena beton sudah runtuh dan nilai $\varepsilon s$ sebesar 0,0290 . Sedangkan nilai $P$ sebesar 
111,6 kN memiliki nilai $\varepsilon c$ sebesar 0,03211 karena beton sudah runtuh (menurun) dan nilai $\varepsilon s$ sebesar 0,0242 .

Pada $P$ sebesar $8,1 \mathrm{kN}$ mencapai lendutan sebesar $0,16 \mathrm{~mm}$ dan saat $P$ mengalami penambahan beban sebesar 49,5 kN maka lendutan yang di miliki sebesar $3,8 \mathrm{~mm}$. Sehingga untuk mencapai keruntuhan pada balok 3D16 CFRP maka diperlukan penambahan $P$ sebesar 100,62 kN mencapai lendutan sebesar 11,42 $\mathrm{mm}$. Sehingga untuk mencapai keruntuhan pada balok 3D16 CFRP maka diperlukan penambahan $\mathrm{P}$ sebesar 118,26 kN mencapai lendutan sebesar 46,04 mm. Pada saat $P$ sebesar $111,6 \mathrm{kN}$ sudah mengalami keruntuhan pada balok 3D16 CFRP dengan lendutan sebesar 59,84 mm. Sehingga dapat dihitung daktilitasnya dengan lendutan sebesar $\delta y=2,92 \mathrm{~mm}$. Sedangkan nilai $\delta u=$ $59,96 \mathrm{~mm}$ sehingga diperoleh nilai daktilitas perpindahan balok 3D16 CFRPsebesar $20,5343$.

\section{Balok beton bertulang tanpa menggunakan CFRP (4D16Normal).}

Lendutan dan retak pertama yang terjadi pada balok tanpa menggunakan perkuatan CFRP dapat dilihat melalui Gambar 15. Retak pertama yang terjadi pada balok 4D16 Normal (tanpa CFRP).
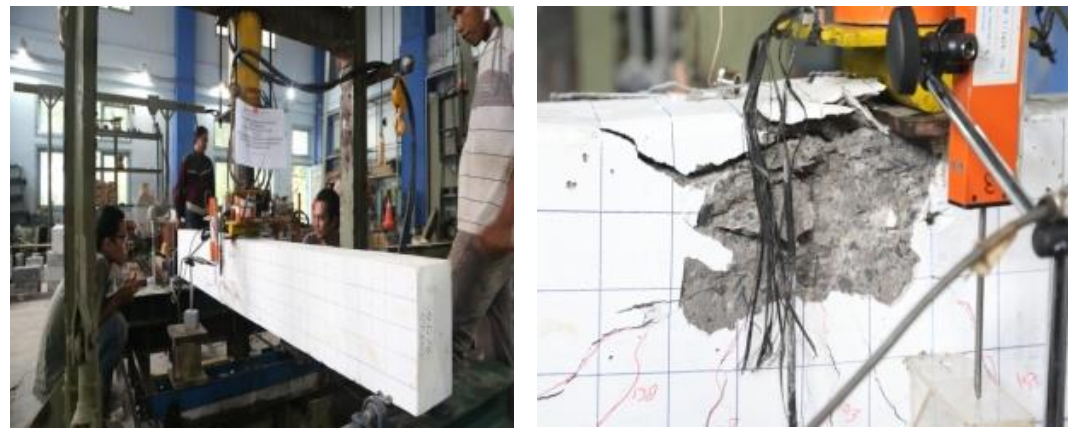

Gambar 19. Retak pertama yang terjadi pada balok 4D16 Normal (tanpa CFRP)

Retak Pertama yang terjadi pada balok beton bertulang Normal dapat dilihat pada Gambar 19. Retak pertama yang terjadi pada balok 4D16 Normal terjadi saat beban menunjukan angka sebesar 17,1 kN. Hubungan antara beban dengan lendutan pada balok beton untuk Balok 4D16 Normal ditunjukam pada Gambar 16. Hubungan antara beban dan lendutan pada Balok 4D16 Normalmenghasilkan $P$ maksimum adalah sebesar 161,28 kN. Balok 4D16 Normal mengalami keruntuhan pada balok sampai pecah karena adanya perencanaan awal dengan nilai $\rho$ mendekati over reinfoced dengan nilai $\rho$ sebesar 0,0235 sedangkan untuk nilai $\rho$ maks sebesar 0,0236 maka balok mengalami pecah pada pengujian balok 4D16 Normal. Berdasarkan grafik hubungan beban-lendutan dapat dilihat pada Gambar 20.

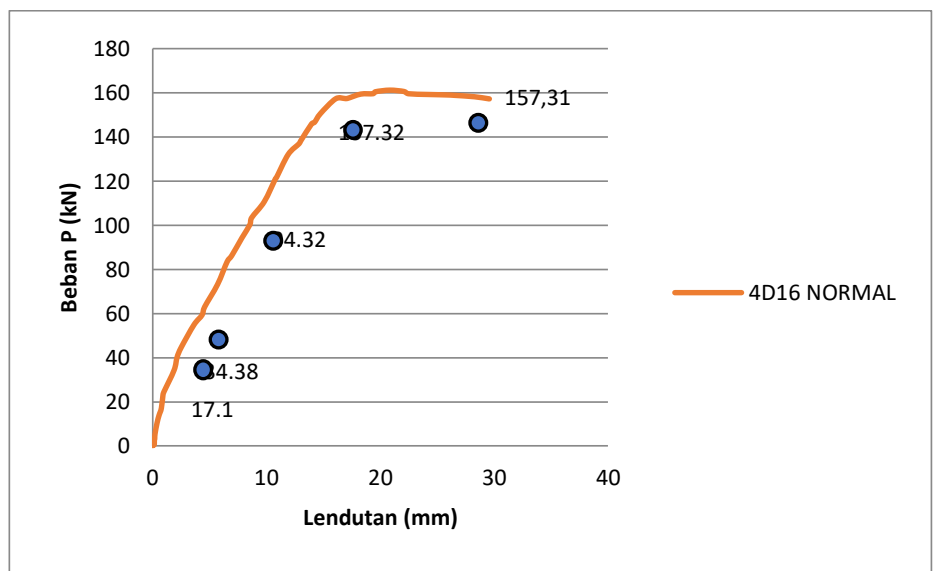

Gambar 20. Hubungan antara beban dan lendutan pada balok 4D16 Normal (Tanpa CFRP) 
Pada $\mathrm{P}$ sebesar $17,1 \mathrm{kN}$ memiliki nilai $\varepsilon \mathrm{c}$ sebesar 0,00039 dan nilai $\varepsilon s$ sebesar 0,0002 . Sedangkan pada $P$ sebesar 34,38 kN memiliki nilai $\varepsilon c \quad 0,0009$ dan nilai $\varepsilon S$ sebesar 0,0004 . Sedangkan nilai $P$ sebesar 94,32 kN memiliki nilai $\varepsilon c$ 0,0030 karena beton sudah runtuh dan nilai $\varepsilon s$ sebesar 0,0015 . Sedangkan nilai $P$ sebesar 157,32 kN memiliki nilai $\varepsilon c 0,0162$ karena beton sudah runtuh dan nilai $\varepsilon$ s sebesar 0,01047. Pada $P$ sebesar $17,1 \mathrm{kN}$ mencapai lendutan sebesar $0,76 \mathrm{~mm}$ dan saat $P$ mengalami penambahan beban sebesar $34,38 \mathrm{kN}$ maka lendutan yang di miliki sebesar $1,88 \mathrm{~mm}$. Sehingga untuk mencapai keruntuhan pada balok 4D16 Normal maka diperlukan penambahan $\mathrm{P}$ sebesar $94,32 \mathrm{kN}$ mencapai lendutan sebesar 7,84 mm. Sehingga untuk mencapai keruntuhan pada balok 4D16 Normal maka diperlukan penambahan $P$ sebesar 157,32 kN mencapai lendutan sebesar 16,06 mm. Pada saat $P$ sebesar $157,31 \mathrm{kN}$ sudah mengalami keruntuhan pada balok 4D16 Normal dengan lendutan sebesar 29,58 mm. Sehingga dapat dihitung daktilitasnya dengan lendutan sebesar $\delta y=$ $3,62 \mathrm{~mm}$. Sedangkan nilai $\delta \mathrm{u}=29,58 \mathrm{~mm}$ sehingga diperoleh nilai daktilitas perpindahan balok 4D16 Normal sebesar 8,1713 .

\section{Balok beton bertulang menggunakan perlakuan CFRP (4D16 CFRP).}

Retak Pertama yang terjadi pada balok beton bertulang perkuatan CFRP dapat dilihat pada Gambar 21. Retak pertama yang terjadi pada balok 4D16 CFRP terjadi saat beban menunjukan angka sebesar $17,1 \mathrm{kN}$. Hubungan antara beban dengan lendutan pada balok beton dengan perkuatan CFRP untuk Balok 4D16 CFRP ditunjukam pada Gambar. 18. Hubungan antara beban dan lendutan pada Balok 4D16 dengan perlakuan CFRPmenghasilkan $\mathrm{P}$ maksimum adalah sebesar $162,64 \mathrm{kN}$.
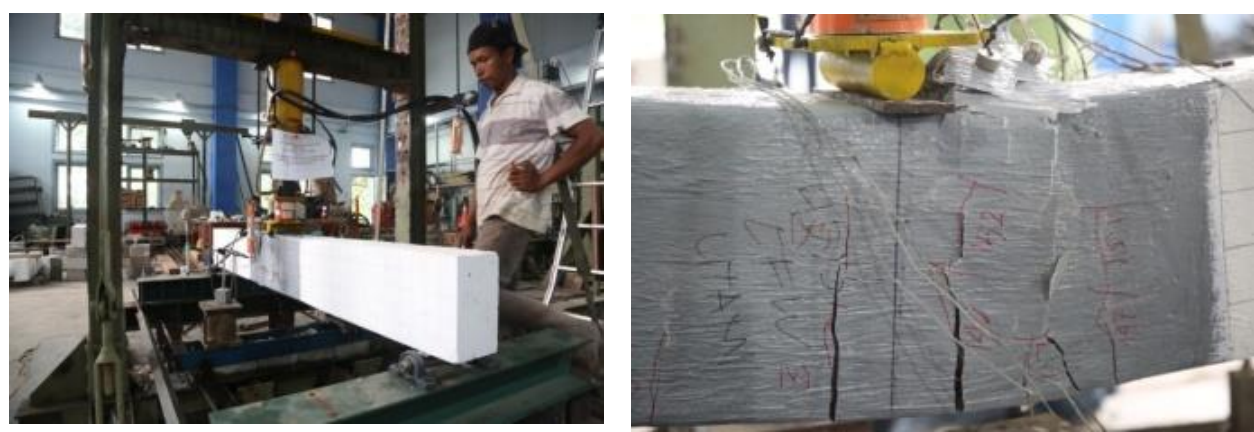

Gambar 21. Retak pertama yang terjadi pada balok 4D16 CFRP.

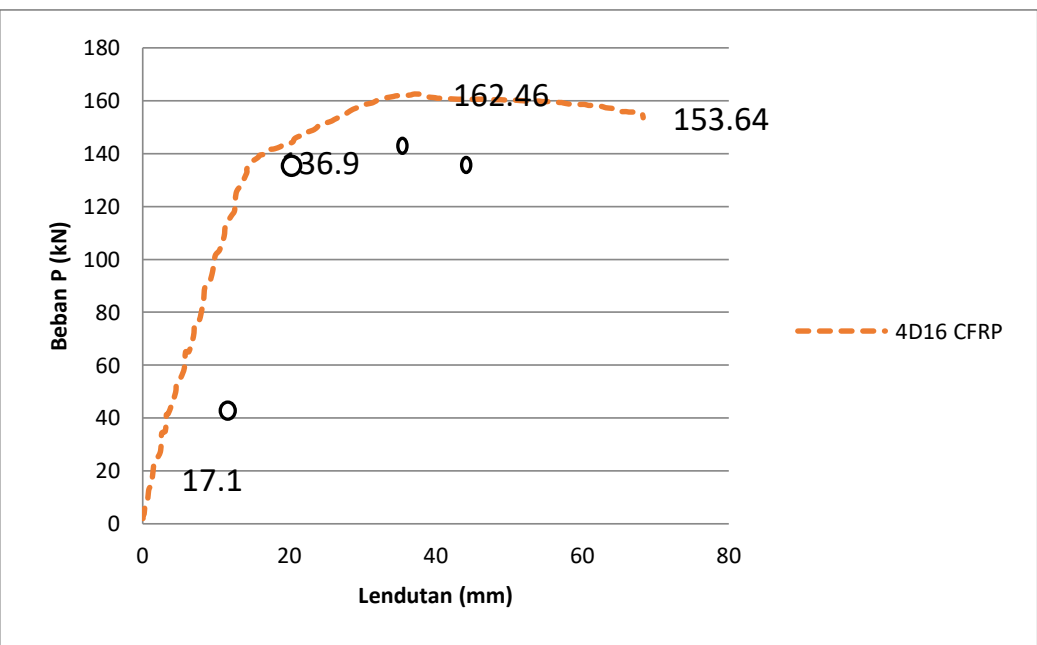

Gambar 22. Hubungan antara beban dan lendutan pada Balok 4D16 dengan perlakuan CFRP 
Berdasarkan pengujian Balok CFRP 4D16 menghasilkan keruntuhan yang sesuai dengan keruntuhan rencana. Pengujian pada balok dengan perlakuan CFRP diperoleh nilai $P$ maksimum adalah sebesar $162,64 \mathrm{kN}$ dengan nilai first crack $17,1 \mathrm{kN}$. Pada $\mathrm{P}$ sebesar $17,1 \mathrm{kN}$ memiliki nilai $\varepsilon \mathrm{C}$ sebesar 0,0005 dan nilai \&s sebesar 0,0002. Sedangkan pada $P$ sebesar $136,9 \mathrm{kN}$ memiliki nilai $\varepsilon c 0,0053$ dan nilai $\varepsilon$ s sebesar 0,0026 . Sedangkan nilai $P$ sebesar 162,64 $\mathrm{kN}$ memiliki nilai $\varepsilon c$ sebesar 0,0130 karena beton sudah runtuh dan nilai $\varepsilon$ s sebesar 0,0088 . Sedangkan nilai $P$ sebesar 153,64 kN memiliki nilai $\varepsilon c 0,0118$ karena beton sudah runtuh (menurun) dan nilai $\varepsilon$ s sebesar 0,0078 .

Pada $\mathrm{P}$ sebesar $17,1 \mathrm{kN}$ mencapai lendutan sebesar $1,28 \mathrm{~mm}$ dan saat $P$ mengalami penambahan beban sebesar $136,9 \mathrm{kN}$ maka lendutan yang di miliki sebesar $14,86 \mathrm{~mm}$. Sehingga untuk mencapai keruntuhan pada balok 4D16 CFRP maka diperlukan penambahan $\mathrm{P}$ sebesar 162,64 kN mencapai lendutan sebesar $37,1 \mathrm{~mm}$. Pada saat $P$ sebesar $153,64 \mathrm{kN}$ sudah mengalami keruntuhan pada balok 4D16 CFRP dengan lendutan sebesar $68,3 \mathrm{~mm}$. Sehingga dapat dihitung daktilitas perpindahan diperoleh sebesar $\delta y=4,62 \mathrm{~mm}$. Sedangkan nilai $\delta \mathrm{u}$ $=68,3 \mathrm{~mm}$ sehingga diperoleh nilai daktilitas balok 4D16 CFRP sebesar 14,7749.

\section{Balok beton bertulang menggunakan perlakuan CFRP (5D16 CFRP).}

Retak pertama yang terjadi pada balok beton bertulang perkuatan CFRP dapat dilihat pada gambar 24 . Retak pertama yang terjadi pada balok 5D16 CFRP terjadi saat beban menunjukan angka sebesar 47,52 kN. Hubungan antara bebandengan lendutan pada balok beton dengan perkuatan CFRP untuk Balok 5D16 CFRP ditunjukam pada Gambar 24. Hubungan antara beban dan lendutan pada Balok 5D16 dengan perlakuan CFRP menghasilkan $\mathrm{P}$ maksimum adalah sebesar $173,16 \mathrm{kN}$.

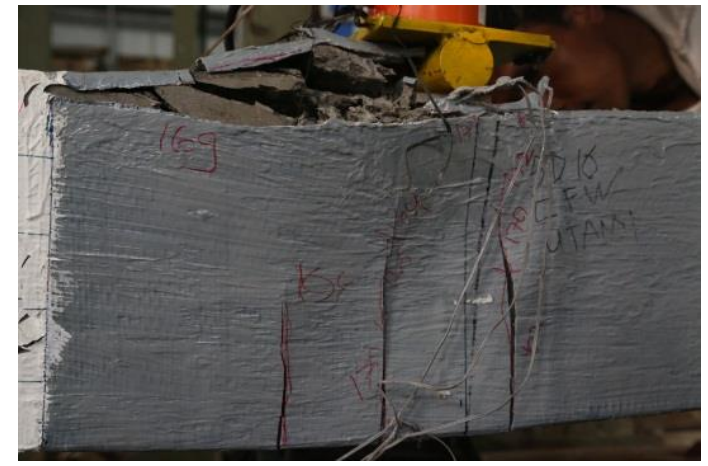

Gambar 23. Retak pertama yang terjadi pada balok 5D16 CFRP

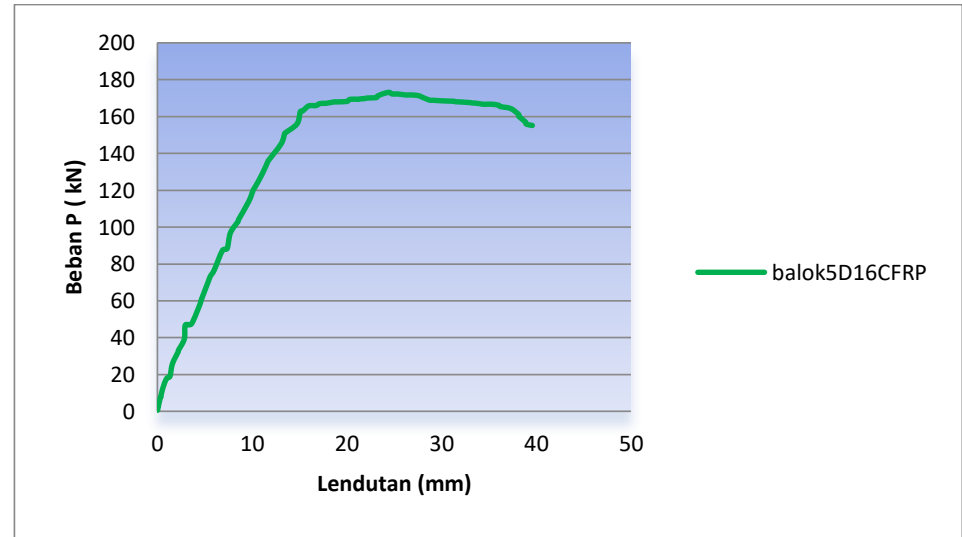

Gambar 24. Hubungan antara beban dan lendutan pada Balok 5D16 dengan perlakuan CFRP 
Berdasarkan pengujian Balok CFRP 5D16 menghasilkan keruntuhan yang sesuai dengan keruntuhan rencana. Pengujian pada balok dengan perlakuan CFRP diperoleh nilai $P$ maksimum adalah sebesar $173,16 \mathrm{kN}$ dengan nilai first crack 47,52 kN. Pada $P$ sebesar $47,52 \mathrm{kN}$ memiliki nilai $\varepsilon \mathrm{c}$ sebesar 0,0003 dan nilai $\varepsilon s$ sebesar 0,0006. Sedangkan pada $\mathrm{P}$ sebesar 135,9 kN memiliki nilai $\varepsilon c \quad 0,0009$ dan nilai $\varepsilon s$ sebesar 0,00204 . Sedangkan nilai $P$ sebesar 173,16 kN memiliki nilai $\varepsilon c$ sebesar 0,00122 karena beton sudah runtuh dan nilai $\varepsilon$ s sebesar 0,0077 . Sedangkan nilai $P$ sebesar 155,16 kN memiliki nilai $\varepsilon c 0,0015$ karena beton sudah runtuh (menurun) dan nilai $\varepsilon s$ sebesar 0,006 .

Pada $P$ sebesar $32,4 \mathrm{kN}$ mencapai lendutan sebesar $2,2 \mathrm{~mm}$ dan saat $P$ mengalami penambahan beban sebesar $135,9 \mathrm{kN}$ maka lendutan yang di miliki sebesar 11,68 mm. Sehingga untuk mencapai keruntuhan pada balok 5D16 CFRP maka diperlukan penambahan $\mathrm{P}$ sebesar 173,16 kN mencapai lendutan sebesar 24,42 $\mathrm{mm}$. Pada saat $\mathrm{P}$ sebesar 155,16 kN sudah mengalami keruntuhan pada balok 5D16 CFRP dengan lendutan sebesar $39,56 \mathrm{~mm}$. Sehingga dapat dihitung daktilitas perpindahan diperoleh sebesar $\delta y=2,2$ $\mathrm{mm}$. Sedangkan nilai $\delta u=41,16 \mathrm{~mm}$ sehingga diperoleh nilai daktilitas balok 5D16 CFRP sebesar 18,71.

\section{Hubungan Momen Dan Kurvatur}

Hasil hubungan momen dan kurvatur dapat disimpulkan bahwa dengan perkuatan CFRP ini balok masih dapat menerima beban sebesar beban perkuatan CFRP. Balok beton 3D16 Normal memiliki momen nominal sebesar 52,02 kNm sedangkan 3D16 dengan perlakuan CFRP memiliki momen maksimum 59,76 kNm. Balok beton 4D16 Normal memilki kapasitas lentur sebesar 80,64 kNm sedangkan 4D16 dengan perlakuan CFRP memiliki kapasitas lentur $81,32 \mathrm{kNm}$ Sedangkan 5D16 dengan perlakuan CFRP memiliki kapasitas lentur sebesar 86,58 kNm PenambahanCFRP sangat mempengaruhi dalam pengujian balok beton bertulang sangat mempengaruhi peningkatan kapasitas momen maksimum pada balok beton bertulang

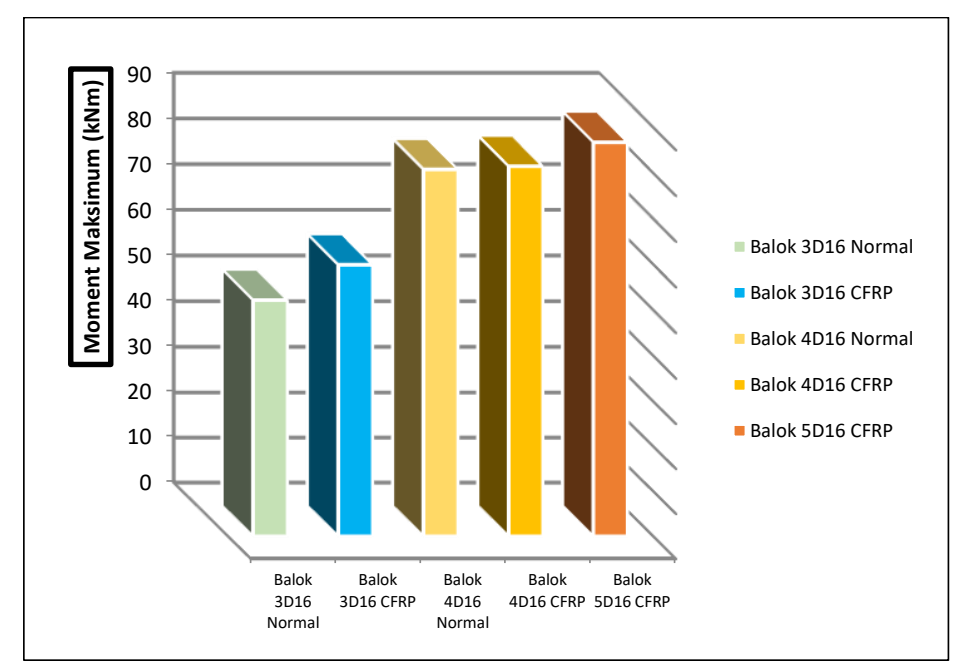

Gambar 25. Grafik momen maksimum yang dapat diterima balok beton bertulang. 


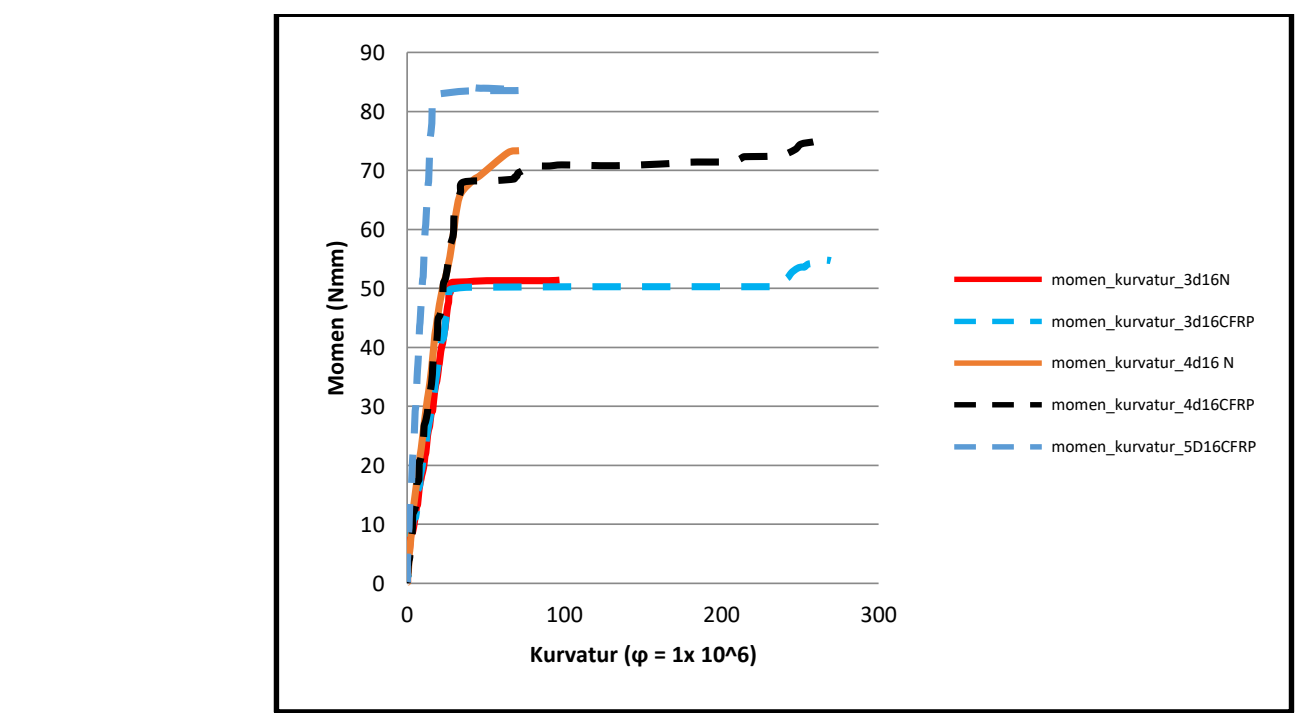

Gambar 26. Hubungan antara momen dan kurvatur pada balok 3D16 Normal, balok 3D16 CFRP, balok 4D16 Normal dan balok 4D16 CFRP serta balok 5D16 CFRP.

Hasil perbandingan antara beban- lendutan pada Balok Normal dengan Balok Perkuatan CFRP. Dari Hasil pengujian menunjukan bahwa dengan penambahan CFRP mengalami peningkatan. Pada balok 3D16 Normal yang memiliki nilai momen nominal maksimumnya sebesar $52,02 \mathrm{kNm}$ setelah dilakukan pemotongan pada grafik hubungan antara momen dan kurvatur pada balok 3D16 Normal memiliki nilai momen nominal sebesar 51,39 kNm. Dan penambahan perkuatan CFRP menghasilkan momen nominal maksimum pada balok 3D16 CFRP sebesar 59,76 kNm setelah dilakukan pemotongan pada grafik hubungan antara momen dan kurvatur pada balok 3D16 CFRP memiliki nilai momen

\section{SIMPULAN}

Berdasarkan hasil pembahasan dapat diambil kesimpulan sebagai berikut:

1. Kapasitas lentur pada balok 3D16 Normal sebesar 51,39 kNm dan balok 3D16 CFRP sebesar $54,81 \mathrm{kNm}$. Sehingga dengan pembalutan CFRP sangat mempengaruhi peningkatan kapasitas lentur sebesar $13 \%$. Kapasitas lentur pada balok 4D16 Normal sebesar 75,33 $\mathrm{kNm}$ dan balok 4D16 CFRP sebesar $76,57 \mathrm{kNm}$ sedangkan untuk balok 5D16 CFRP sebesar 86,58 kNm.

2. Daktilitas perpindahan pada balok 3D16 Normal sebesar 13,7971 dan balok 3D16 nominal sebesar $54,81 \mathrm{kNm}$. Pada balok 4D16 Normal yang memiliki nilai momen nominal maksimumnya sebesar 80,64 kNm setelah dilakukan pemotongan pada grafik hubungan antara momen dan kurvatur pada balok 4D16 Normal memiliki nilai momen nominal sebesar $75,33 \mathrm{kNm}$. Sedangkan untuk balok 4D16 CFRP momen nominal maksimum yang tercapai $81,32 \mathrm{kNm}$ setelah dilakukan pemotongan pada grafik hubungan antara momen dan kurvatur pada balok 4D16 CFRP memiliki nilai momen nominal sebesar $76,57 \mathrm{kNm}$, sedangkan untuk balok 5D16 CFRP memiliki momen nominal sebesar $86,58 \mathrm{kNm}$. Penggunaan $C F R P$ sangat mempengaruhi dalam pengujian balok beton bertulang.
CFRP sebesar 20,5343. Daktilitas perpindahan pada balok 4D16 Normal sebesar 8,1713 dan balok 4D16 CFRP sebesar 14,7836 sedangkan untuk balok 5D16 CFRP sebesar 18,71. Sehingga dengan pembalutan CFRP sangat mempengaruhi peningkatan daktilitas.

3. Kondisi kegagalan CFRP pada balok normal dan perkuatan CFRP adalah rusaknya CFRP (sobek), dimana kerusakan CFRP lebih dominan pada mengelupasnya CFRP dari balok. 
Berdasarkan pengujian, pemakaian CFRP dapat meningkatkan kuat geser dibandingkan dengan balok normal. Dalam hasil analisis perhitungan perencanaan balok normal tanpa perlakuan CFRP memiliki kuat geser sebesar 158,5974 kN dan balok yang diberikan perlakuan CFRP memiliki kuat geser sebesar 205,9511 kN. Hasil ini

\section{DAFTAR RUJUKAN}

ACl 440.2R-08. (2008). "Guide for the Design and Construction of Externally Bonded FRP Systems for Strengthening Concrete Structures", ACl Commite 440.

Nawy, Edward G. (1995). Reinforced $A$ fundamental Approach. Department of Civil and Enviromental Engeenering. Rutgers University. The State University of New Jearsey. New Jearsey

Pangestuti Endah Kanti. (2006). "Penggunaan Carbon Fiber Reinforced Plate Sebagai Tulangan Eksternal pada Struktur Balok Beton." Universitas Negeri Semarang.

Paulay, T., and Priestley, M.J.N. (1992). "Seismic Design of Reinforced Concrete and Masonry Buildings", John Wiley \& Sons, Inc., New York.

Paulay, T., and Priestley, M.J.N. (1992). Seismic Design of Reinforced Concrete and Masonry Buildings, JohnWiley \& Sons, Inc., New York.

Prihadi, W. R., \& Pratama, G. N. I. P. (2016). Konfigurasi Batang Pada Perancangan membuktikan bahwa dengan benda uji dan pemasangan CFRP sesuai pada kajian diperoleh hasil yang sesuai dengan standar $\mathrm{ACl} 440$, sehingga masih aman dan dapat digunakan referensi dalam rangka perkuatan balok dengan kondisi pada saat momen positif maupun momen negatif sebagai perilaku balok saat terjadi gempa.

Rangka Atap Bambu. INformasi dan Ekspose hasil Riset Teknik Slpil dan Arsitektur, 12(2), 173-183.

Prihanantio Januar, Pangestuti Endah Kanti. (2006). "Analisis Kuat Lentur Balok Beton Bertulang dengan Carbon Fiber Wrap." Universitas Diponegoro Semarang.

Santoso H M. (2000) Sika Strengthening System, PT. Sika Nusa Pratama, Semarang.

$$
\begin{aligned}
& \text { SNI - } 03-2847 \text { - S2013. (2013). "Tata Cara } \\
& \text { Perhitungan Struktur Beton untuk } \\
& \text { Bangunan Gedung" }
\end{aligned}
$$

Umbu Nday Albert Aun. (2012). "Kapasitas Lentur Balok Beton Bertulang Perkuatan Carbon Fiber Wraps (CFRP) (Balok Dibebani Oleh Beberapa Kondisi Pembebanan Awal Dan Kemudian Diperkuatan Dengan CFRP)". Universitas Gadjah Mada.

Sri Rejeki Laku Utami. (2016). "Pengaruh Pembalutan Carbon Fiber Wrap (CFW) Terhadap Daktilitas Balok Beton Bertulang". Universitas Diponegoro. 